\title{
Hydroxy-L-prolines as asymmetric catalysts for aldol, Michael addition and Mannich reactions
}

\author{
Lo'ay A. Al-Momani* \\ *Department of Chemistry, Tafila Technical University, P. O. Box 179,Tafila, 66110 Jordan \\ E-mail: loay.al-momani@daad-alumni.de
}

DOI: http://dx.doi.org/10.3998/ark.5550190.0013.609

\begin{abstract}
The hydroxyprolines (Hyps) 2-6 are tested as organocatalysts for aldol, Michael additions, and Mannich reactions. The results are compared with the well-known analogous L-proline (1).The effect of the additional hydroxyl group and chiral center was investigated in the three types of reactions. Catalyst $\mathbf{2}$ shows an enhancement in the stereoselectivity of the aldol reaction, while $\mathbf{3}$ in Michael addition and $\mathbf{5}$ in Mannich reaction give the best results. Derivatives of hydroxyprolines show diversity in the catalytic behavior like 6.
\end{abstract}

Keywords: Hydroxyprolines, organocatalysis, chemoenzymatic synthesis, amino acids

\section{Introduction}

L-Proline (1) is one of the most well-known organocatalysts. ${ }^{1}$ It has been used over a wide range of organic synthesis reactions to obtain enantiomerically or diastereomerically highly enriched

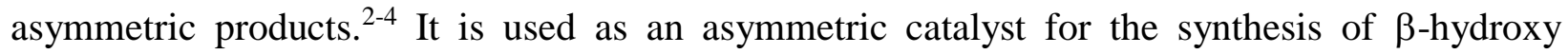
ketones via aldol additions, ${ }^{5-11}$ Michael addition reactions, ${ }^{12-15}$ and $\beta$-amino ketones via Mannich reactions. ${ }^{16,17}$ The importance of L-proline (1) - more than all other amino acids as catalyst derives from the fact that it is the only secondary proteinogenic amino acid, and it has a special rigidity which could control the stereochemistry through the formed imine/enamine intermediate. ${ }^{16-20}$ Moreover, L-proline is a natural amino acid, and it is available in very pure form and is inexpensive. Modification and derivatization ${ }^{21-25}$ of L-proline (1) have been the target of many groups working to improve the efficiency of its catalytic behavior. The carboxylic acid moiety ${ }^{26-29}$ as well as the ring $\mathrm{C}$-atoms have been the targets of most modifications.

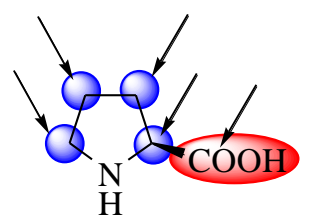


Transformation of the carboxylic acid moiety (red) into an amide or peptide bond was the main idea to obtain more efficient and selective catalysts for the aldol addition. ${ }^{26-32}$ The effect of chiral centers on the amide group was also studied. High activity and enantioselectivity were observed for prolinamide derivatives with chiral auxiliaries. ${ }^{23,33-36}$ Another thought was to exchange the carboxylate group with other functional groups. An improvement in the activity and stereoselectivity was observed in many cases. ${ }^{21,22,37-39}$ The main C-skeleton modifications divide into two main themes: insertion of a heteroatom in the ring, such as sulfur, ${ }^{9,19}$ or replacement of C-hydrogen with another group at one or more of the ring positions (blue). ${ }^{19,40-42}$

The hydroxyprolines 2-5 and some of their derivatives like 6 are supposed to be very valuable L-proline derivatives. Hydroxprolines 2-5 are prepared from L-proline via enzymatic hydroxylation reactions. These hydroxylations were carried out by Hüttel and Klein, ${ }^{43,44}$ and were performed at gram scales. The trans-4-isomers and some derivatives have been known for a long time and tested as catalysts for aldol additions and other reactions. ${ }^{9,19,45}$ Very few studies are reported on cis-isomers. Several studies were conducted on a Zn-proline complex as an asymmetric catalyst. ${ }^{46-48}$ The hydroxyprolines 2-5 and the tert-butyl ether $\mathbf{6}$ are the targets of this study. The results of all hydroxyprolines and their derivatives are compared with L-proline (1) under the same conditions. Three asymmetric reactions are studied: aldol addition reactions, Mannich reactions, and the Michael addition reactions. Here, enzymatic ${ }^{43}$ or microbial $^{49-51}$ access $^{2}$ of all regio- and stereoisomeric hydroxyprolines is combined with a thorough investigation of the influence on stereoselectivity in asymmetric catalysis.

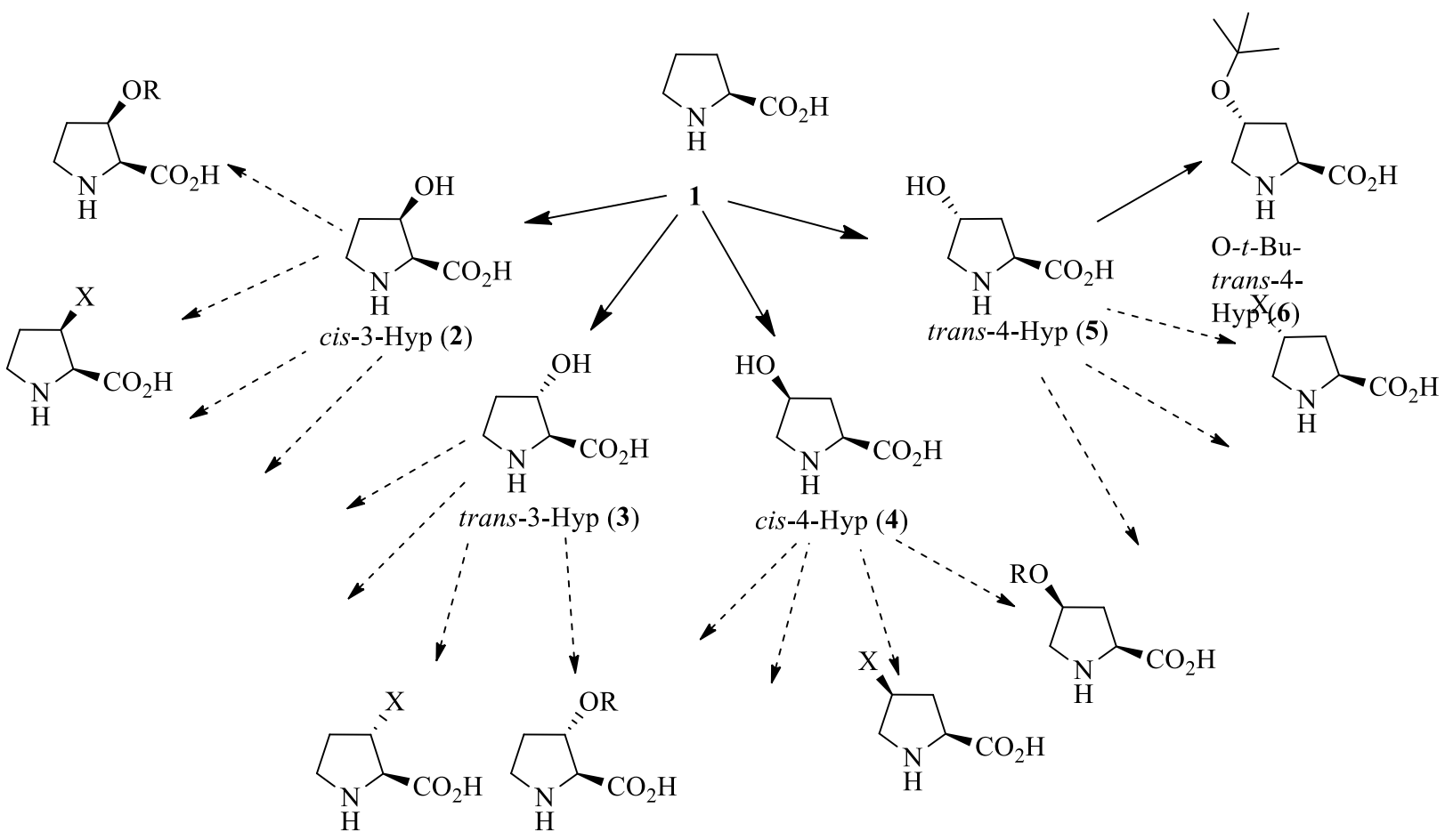

Scheme 1. Hydroxyprolines and some proposed derivatives. 
Recently, Müller et al. published results of aldol reactions using a $\mathrm{Zn}$-complex of some chorismate metabolites such as trans-2,3-CHA and trans-3,4-CHA which showed high enantioselectivity in the aldol addition. ${ }^{52,53}$ Hüttel et al. studied the influence of hydroxyproline derivatives and some other non-proteinogenic amino acids on the aldol addition and on Michael and Mannich reactions.

\section{Results and Discussion}

\section{Aldol reaction}

A summary of the results of the reaction of 4-nitrobenzaldehyde with acetone is given in Table 1 using the hydroxyprolines $\mathbf{2 - 5}$ and ether $\mathbf{6}$ as catalysts. As mentioned above, the trans-isomers have been tested as organocatalysts, but the cis-isomers are rarely cited in the literature. To make a complete study, it is better to test all hydroxyprolines 2-5 under the same conditions.

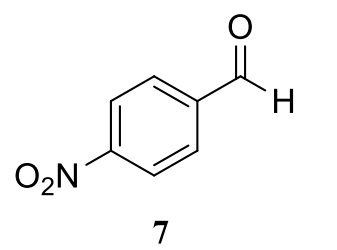

7

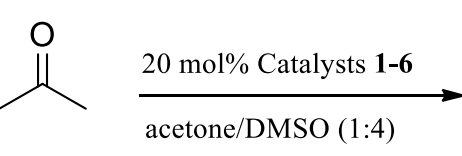

8

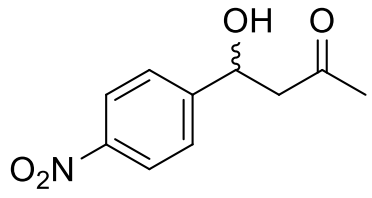

9

Table 1. Summary of the results of aldol-addition reaction

\begin{tabular}{ccccc}
\hline \multirow{2}{*}{ Entry } & \multirow{2}{*}{ Catalyst } & \multicolumn{3}{c}{ Aldol addition reaction } \\
\cline { 3 - 5 } & & Time of reaction (h) & Conversion $(\%)$ & ee (\%) / Isomer \\
\hline 1 & $\mathbf{1}$ & 24 & 100 & $65 /(R)-\mathbf{9}$ \\
2 & $\mathbf{2}$ & 18 & 91 & $74 /(R)-\mathbf{9}$ \\
3 & $\mathbf{3}$ & 20 & 75 & $39 /(R)-\mathbf{9}$ \\
4 & $\mathbf{4}$ & 20 & 86 & $55 /(R)-\mathbf{9}$ \\
5 & $\mathbf{5}$ & 18 & 100 & $57 /(R)-\mathbf{9}$ \\
6 & $\mathbf{6}$ & 18 & 89 & $69 /(R)-\mathbf{9}$ \\
\hline
\end{tabular}

All results are compared with the naturally L-proline (1). It is obvious from the results that the cis-3-hydroxyproline (2) gave the best outcome of about $91 \%$ conversion and $74 \%$ ee, while L-proline (1) showed a quantitative conversion and 65\% ee. It seems that the hydroxyl group in the cis-isomer 2 affects the transition state via intramolecular hydrogen bonding and assists the attack from one side which enhances the ee (Scheme 1, I-IV). The yield and the ee of the trans3-Hyp (3) are significantly less under the same conditions. The inversion of stereocenter at position 3 diminishes the stereoselectivity of the aldol addition reaction. The intermolecular 
hydrogen bond made by the hydroxy group at position 3 of trans-isomer (3) could be the reason for this decrease in the enantioselectivity.

In the case of the 4-Hyp, both cis-isomer (4) and trans-isomer (5) gave a very good yield and almost similar enantioselectivities, (ee of about 55-57\%). As the hydroxyl group is located further away from the carboxylic acid group, this could result in weakening of H-bonding in both

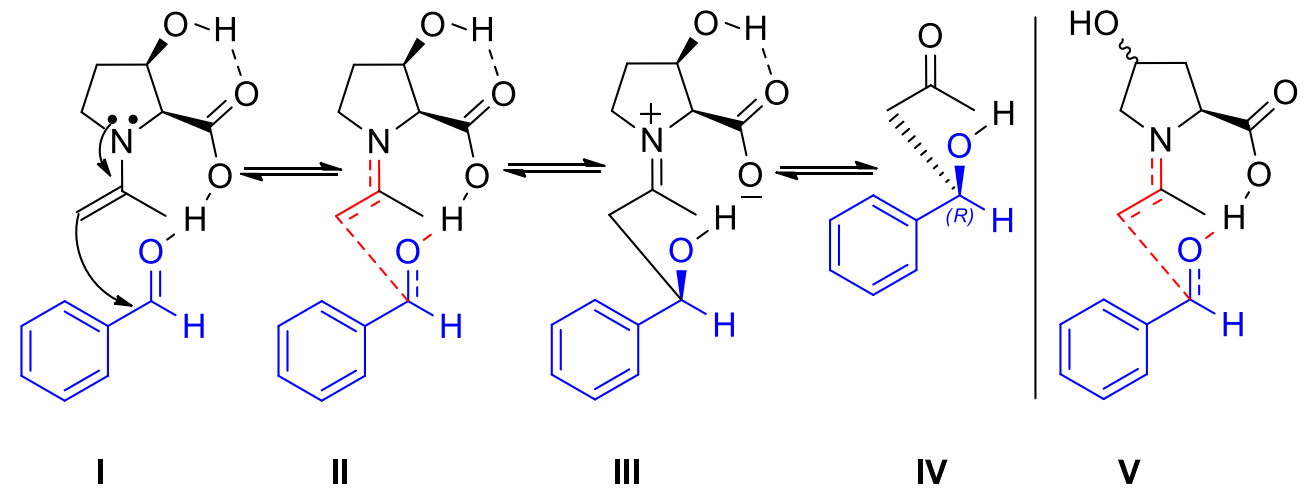

Scheme 2. Description of imine/enamine intermediate of the aldol mechamism.

cases by preventing the intramolecular interaction between the hydroxy and the carboxylic acid groups (Scheme 2, V). Intermolecular hydrogen bonding is suggested. This led to a decrease in the stereoselectivity by about 10-20\% compared with L-proline (1) $(65 \%$ ee $)$ and cis-3hydroxyproline (2) (74\% ee).

Some calculations were carried out using the ChemDraw program. They showed an indication of the effect of the intramolecular hydrogen-bonding in both cases of 3-cis- (2) and 4cis-Hyp (4), while the hydroxy groups in both cases of $\mathbf{3}$ and $\mathbf{5}$ have no intramolecular interaction (Figure 1)

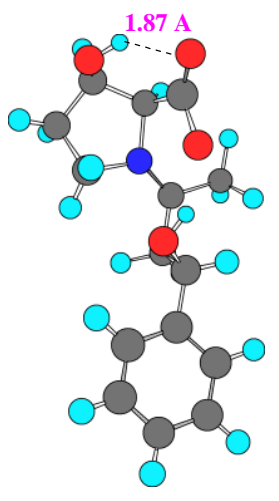

3-cis-Hyp (2)

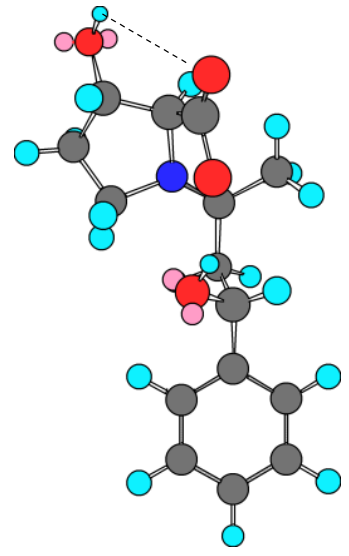

3-trans-Hyp (3)

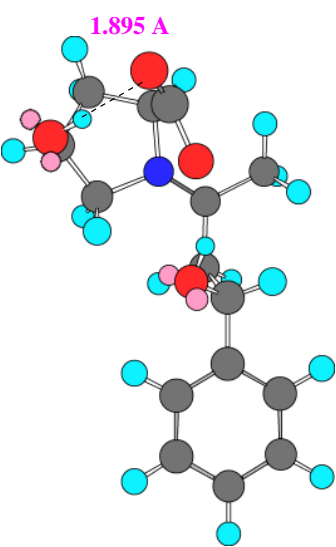

4-cis-Hyp (4)

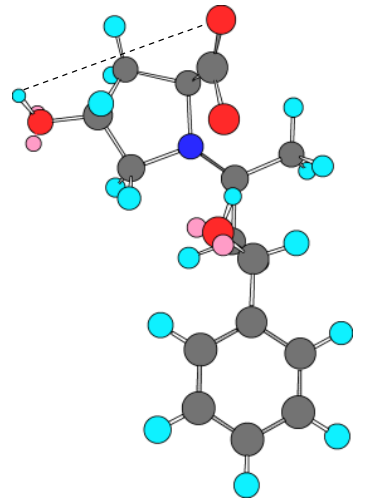

4-trans-Hyp (5)

Figure 1. The close contact between the hydroxyl and the carboxylic acid groups in Hyps. 
The hydroxyl group in the trans-4-Hyp (5) is substituted with a bulky tert-butyl-group in compound 6. That results in the enhancement of the ee of compound 9. Ether $\mathbf{6}$ almost shows the same selectivity (ee $=69 \%$, coversion of $89 \%$ ) as that for L-proline (1) (ee $=65 \%$, conversion of $100 \%)$ and lower conversion. The termination of intermolecular hydrogen bonding is suggested to be responsible for this result. Catalyst $\mathbf{6}$ behaves as if it were L-proline (1). Also, the tert-butyl group partially blocks one side and assists the attack to come from the other side.

\section{Michael addition}

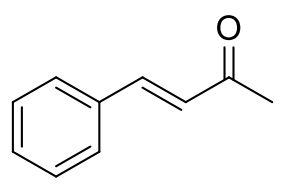

10

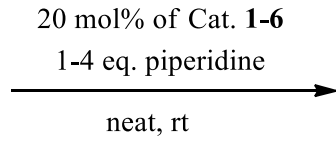

11

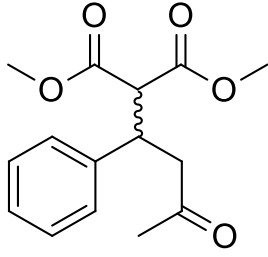

12

Table 2. Summary of the results of Michael addition reaction

\begin{tabular}{ccccc}
\hline \multirow{2}{*}{ Entry } & Catalyst & \multicolumn{3}{c}{ Michael addition reaction } \\
\cline { 3 - 5 } & & Time of reaction (day) & Conversion (\%) & $e e(\%)$ \\
\hline 1 & $\mathbf{1}$ & 2 & 100 & 25 \\
2 & $\mathbf{2}$ & 2 & 93 & $<5$ \\
3 & $\mathbf{3}$ & 2 & 100 & 27 \\
4 & $\mathbf{4}$ & 2 & 92 & $<5$ \\
5 & $\mathbf{5}$ & 3 & 84 & $<5$ \\
6 & $\mathbf{6}$ & 2 & 100 & 19 \\
\hline
\end{tabular}

Hydroxyprolines 1-6 were studied in a Michael addition reaction (Table 2). In general, it seems that the presence of the hydroxy group does affect the enantiomeric excess (ee). In most cases, an $e e$ of $<5 \%$ was observed. In the case of trans-3-Hyp (3) as catalyst, the ee was similar to that observed for L-proline (1) itself. It is proposed that the hydroxy group attached to the proline ring disturbs the hydrogen bonding in the imine/enamine intermediate. This results in decreased enantioselectivity. In the case of catalyst $\mathbf{6}$, substitution of the hydroxyl group by tertbutoxy group enhances the conversion as well as the enantioselectivity of the Michael reaction.

\section{Mannich reaction}

L-Proline (1) and hydroxyprolines 2-6 were studied as catalysts in the Mannich reaction of 4nitrobenzaldehyde $\mathbf{7}$, acetone $\mathbf{8}$, and aniline 13 with conversions in the range $75-95 \%$. Therefore, they almost have the same effect on the yield. However, a dramatic effect is seen on 
enantioselectivity. Both cis- and trans-3-Hyps ( 2 and $\mathbf{3}$ respectively) showed a decrease in the ee in comparison with L-proline (1). The presence of the hydroxyl group adjacent to the carboxyl group inhibits the selectivity of the reaction because of the strong intramolecular hydrogen bonding (Table 3).<smiles>O=Cc1ccc([N+](=O)[O-])cc1</smiles>

7<smiles>CC(C)=O</smiles>

8<smiles>COc1ccc(N)cc1</smiles>

13

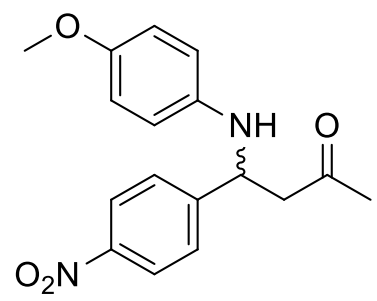

14

Table 3. Summary of the results of Mannich reaction

\begin{tabular}{ccccc}
\hline \multirow{2}{*}{ Entry } & \multirow{2}{*}{ Catalyst } & \multicolumn{3}{c}{ Michael addition reaction } \\
\cline { 3 - 5 } & & Time of reaction (day) & Conversion (\%) & $e e(\%)$ \\
\hline 1 & $\mathbf{1}$ & 2 & 88 & 54 \\
2 & $\mathbf{2}$ & 2 & 87 & 20 \\
3 & $\mathbf{3}$ & 2 & 79 & 42 \\
4 & $\mathbf{4}$ & 2 & 77 & 61 \\
5 & $\mathbf{5}$ & 2 & 95 & 75 \\
6 & $\mathbf{6}$ & & 94 & 27 \\
\hline
\end{tabular}

Whereas in the case of the cis- and trans-4-Hyps ( $\mathbf{4}$ and $\mathbf{5}$ respectively), the ee is enhanced in comparison with the result of L-proline (1). As the distance between carboxyl group and hydroxyl group increases, the intramolecular forces decrease and the selectivity of Mannich reaction increases. In the Hyp-derivative $\mathbf{6}$, the substitution of hydroxyl with $t$-butoxy group showed no effect on the conversion and had a strong effect on the stereoselectivity in comparison with its precursor 5 (Table 3)

\section{Knoevenagel reaction}

Compounds 1-6 were also tested as catalysts for the Knoevenagel reaction of dimethyl malonate (15) and 3-methylbutyraldehyde (16). Excellent yields of product dimethyl 2-(3methylbutylidene)malonate (17) were obtained for all catalysts 1-6. The yields were of 85-95\%. 


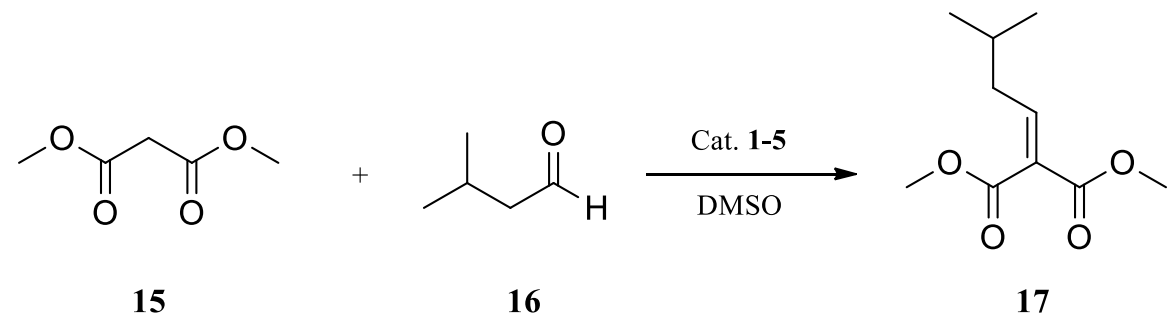

\section{Scheme 3}

\section{Conclusions}

Hydroxyprolines $\mathbf{2}$ and $\mathbf{4}$ are available on a gram scale via chemoenzymatic synthesis while $\mathbf{3}, \mathbf{5}$ and $\mathbf{6}$ are commercially available. Each of these showed variable behaviors as organo-catalysts in aldol addition, Michael, and Mannich reactions. Study of the derivative $\mathbf{6}$ indicates the diversity in the behavior of each hydroxyproline and its possible derivatives. The substitution of the hydroxy group with another group ( $\mathrm{X}=$ halogen, $\mathrm{OR}$ and $\mathrm{NH}_{2}, \ldots$.. etc.) will generate diverse organo-catalysts with different selectivities and efficiencies toward the three reactions and other organo-synthetic reactions.

\section{Experimental Section}

General. All reagents used were of analytical grade. Solvents were dried by standard methods if necessary. TLC was carried out on aluminium sheets precoated with silica gel 60F254 (Merck). Detection was accomplished by UV light $(\lambda=254 \mathrm{~nm})$. Preparative column chromatography was carried out on silica gel 60 (Merck, 40 - $63 \mu \mathrm{m}$ ). ${ }^{1} \mathrm{H}$-NMR spectra were recorded on an AMX400 (Bruker BioSpin, Germany). $\mathrm{CDCl}_{3}(\delta=7.26 \mathrm{ppm}), \mathrm{HDO}(\delta=4.81 \mathrm{ppm})$ and DMSO $(\delta=2.50$ ppm) were used as internal standards. ${ }^{13} \mathrm{C}$-NMR spectra were calibrated with ${ }^{13} \mathrm{CDCl}_{3}(\delta=77.00$ $\mathrm{ppm})$ and DMSO $(\delta=39.43 \mathrm{ppm})$ as internal standard. Ee was determined by chiral phase HPLC (Chiralpak AS-H, Daicel). In the aldol reaction, the eluent was $n$-hexane/isopropanol (70:30), UV $254 \mathrm{~nm}$, flow rate $0.7 \mathrm{~mL} / \mathrm{min}$. $R$-isomer, $t_{R}=13.6 \mathrm{~min}$ and $S$-isomer, $t_{R}=17.3 \mathrm{~min}$. and $25{ }^{\circ} \mathrm{C}$. In the Michael addition reaction, the eluent was $n$-hexane/isopropanol (85:15), UV 254 $\mathrm{nm}$, flow rate $0.7 \mathrm{~mL} / \mathrm{min}$. isomer $1, t_{R}=12.1 \mathrm{~min}$ and isomer $2, t_{R}=14.5 \mathrm{~min} .25^{\circ} \mathrm{C}$. In the Mannich reaction, the eluent was $n$-hexane/isopropanol (90:10), UV $254 \mathrm{~nm}$, flow rate 1.0 $\mathrm{mL} / \mathrm{min}$. isomer $1, t_{R}=30.7 \mathrm{~min}$ and isomer $2, t_{R}=33.5 \mathrm{~min} .25^{\circ} \mathrm{C}$.

\section{Aldol reaction}

Product (9). $p$-Nitrobenzaldehyde (7) $(151 \mathrm{mg}, 1.0 \mathrm{mmol})$ was dissolved in $2 \mathrm{~mL}$ acetone (8). A solution of $23 \mathrm{mg}(0.2 \mathrm{mmol})$ of $\mathbf{1}$ in $10 \mathrm{~mL} \mathrm{DMSO}$ was added and the mixture stirred overnight 
at $\mathrm{rt}$. The reaction mixture was diluted with ethyl acetate and washed twice with water. The organic layer (the product 9) was dried over anhydrous $\mathrm{Na}_{2} \mathrm{SO}_{4} .{ }^{1} \mathrm{H} \mathrm{NMR}(400 \mathrm{MHz}, 298 \mathrm{~K}$, ppm, in $\left.\mathrm{CDCl}_{3}\right): \delta=8.21$ (d, $J=8.8 \mathrm{~Hz}, 2 \mathrm{H}, \mathrm{H}$-arom), 7.54 (d, $J=8.6 \mathrm{~Hz} .2 \mathrm{H}, \mathrm{H}$-arom), 5.26 (dt, $J=3.7 \mathrm{~Hz}, J=7.6 \mathrm{~Hz}, 1 \mathrm{H}, \mathrm{CH}-\mathrm{O}), 3.58(\mathrm{~d}, J=3.3 \mathrm{~Hz}, 1 \mathrm{H}, \mathrm{CO}-\mathrm{CHH}), 2.85(\mathrm{dd}, J=3.4 \mathrm{~Hz}, J=$ $6.1 \mathrm{~Hz}, 1 \mathrm{H}, \mathrm{CO}-\mathrm{CH} H), 2.22$ (s, 3H, CO-CH $), 1.59$ (bs, $1 \mathrm{H}, \mathrm{OH}) .{ }^{13} \mathrm{C} \mathrm{NMR}(101 \mathrm{MHz}, 298 \mathrm{~K}$, ppm, in $\left.\mathrm{CDCl}_{3}\right): \delta=208.47(\mathrm{C}=\mathrm{O}), 149.94$ (C-arom), 147.26 (C-arom), 126.37 (2 x C-arom), 123.72 (2 x C-arom), $68.86(\mathrm{C}-\mathrm{O}), 51.46\left(\mathrm{CO}-\mathrm{CH}_{2}\right), 30.68\left(\mathrm{CO}-\mathrm{CH}_{3}\right)$.

\section{Michael addition}

Product (12). Compound 10 (117 mg, $0.8 \mathrm{mmol})$ was added to 2 eq. of dimethyl malonate (11) $(211 \mathrm{mg}, 1.6 \mathrm{mmol}, 183 \mu \mathrm{L}$ ) and mixed. Piperidine ( 2 eq., $1.6 \mathrm{mmol}, 136 \mathrm{mg}, 158 \mu \mathrm{L}$ ) was added to the mixture and stirred at $\mathrm{rt}$ for $10 \mathrm{~min} .5 .0 \mathrm{mg}(0.04 \mathrm{mmol})$ of Cat. 1 were added. The reaction mixture was stirred to completion and diluted with ethyl acetate. It was washed twice with water. The organic layer (the product 12) was dried over anhydrous $\mathrm{Na}_{2} \mathrm{SO}_{4}$. The reaction was repeated with the same molar ratio using catalysts $2-6 .{ }^{1} \mathrm{H}$ NMR $(400 \mathrm{MHz}, 298 \mathrm{~K}$, ppm, in $\mathrm{CDCl}_{3}$ ): $\delta=7.22-7.09$ (m, $5 \mathrm{H}, \mathrm{H}$-arom), 3.89 (ddd, $J=5.6 \mathrm{~Hz}, J=8.4 \mathrm{~Hz}, J=9.6 \mathrm{~Hz}, 1 \mathrm{H}, \mathrm{CH}_{2}-$ $\mathrm{CH}), 3.65\left(\mathrm{~s}, 3 \mathrm{H}, \mathrm{O}-\mathrm{CH}_{3}\right), 3.63\left(\mathrm{~s}, 3 \mathrm{H}, \mathrm{O}-\mathrm{CH}_{3}\right), 3.48(\mathrm{~m}, 1 \mathrm{H}, \mathrm{CO}-\mathrm{CH}-\mathrm{CO}), 3.29(\mathrm{~m}, 1 \mathrm{H}, \mathrm{CO}-$ $\mathrm{C} H \mathrm{H}), 2.87(\mathrm{dd}, J=5.3 \mathrm{~Hz}, J=6.9 \mathrm{~Hz}, 1 \mathrm{H}, \mathrm{CO}-\mathrm{CHH}), 1.94\left(\mathrm{~s}, 3 \mathrm{H}, \mathrm{CO}-\mathrm{CH}_{3}\right) .{ }^{13} \mathrm{C} \mathrm{NMR}(101$ $\mathrm{MHz}, 298 \mathrm{~K}, \mathrm{ppm}$, in $\left.\mathrm{CDCl}_{3}\right)$ : $\delta=205.58(\mathrm{C}=\mathrm{O}), 168.24(\mathrm{C}=\mathrm{O}), 167.96(\mathrm{C}=\mathrm{O}), 167.72(\mathrm{C}-$ arom), 163.75 (C-arom), 140.10 (C-arom), 128.22 (C-arom), 127.68 (C-arom), 126.95 (C-arom), $56.80\left(\mathrm{O}-\mathrm{CH}_{3}\right), 52.04\left(\mathrm{O}-\mathrm{CH}_{3}\right), 46.81(\mathrm{CO}-\mathrm{CH}-\mathrm{CO}), 40.13\left(\mathrm{CO}-\mathrm{CH}_{2}\right), 29.99\left(\mathrm{CH}-\mathrm{CH}_{2}\right), 24.04$ $\left(\mathrm{CO}-\mathrm{CH}_{3}\right)$.

\section{Mannich product}

Product (14). Compound 7 (50 mg, $0.33 \mathrm{mmol}$ ) was dissolved in $2 \mathrm{~mL}$ of DMSO. 1.1 eq. of compound 13 (44 mg, $0.36 \mathrm{mmol}$ ) was added to the solution. $0.5 \mathrm{~mL}$ of acetone $(\mathbf{8})$ was added to the mixture and stirred at $\mathrm{rt}$ for $10 \mathrm{~min} .16 .0 \mathrm{mg}(0.12 \mathrm{mmol})$ of Cat. 1 were added. The reaction mixture was stirred to completion and diluted with ethyl acetate. The organic layer was washed twice with water. The organic layer (the product 14) was dried over anhydrous $\mathrm{Na}_{2} \mathrm{SO}_{4}$. The reaction was repeated with catalysts $\mathbf{2 - 6}$ using the same molar ratio. ${ }^{1} \mathrm{H} N \mathrm{NM}(400 \mathrm{MHz}, 298 \mathrm{~K}$, ppm, in $\mathrm{CDCl}_{3}$ ): $\delta=8.17$ (d, $J=8.7 \mathrm{~Hz}, 2 \mathrm{H}, \mathrm{H}$-arom), 7.55 (d, $J=8.7 \mathrm{~Hz}, 2 \mathrm{H}, \mathrm{H}$-arom), 6.69 (d, $J=8.9 \mathrm{~Hz}, 2 \mathrm{H}, \mathrm{H}$-arom), $6.46(\mathrm{~d}, J=8.9 \mathrm{~Hz}, 2 \mathrm{H}, \mathrm{H}$-arom), $4.85(\mathrm{t}, J=6.3 \mathrm{~Hz}, 1 \mathrm{H}, \mathrm{CH}-\mathrm{NH})$, 4.23 (bs, $1 \mathrm{H}, \mathrm{NH}), 3.69$ (s, 3H, OCH $\left.H_{3}\right), 2.95\left(\mathrm{~d}, J=6.3 \mathrm{~Hz}, 2 \mathrm{H}, \mathrm{CO}-\mathrm{CH}_{2}\right), 2.15$ (s, 3H, CO$\left.\mathrm{CH}_{3}\right) .{ }^{13} \mathrm{C}$ NMR $\left(101 \mathrm{MHz}, 298 \mathrm{~K}, \mathrm{ppm}\right.$, in $\left.\mathrm{CDCl}_{3}\right): \delta=206.07$ (C=O), 152.74 (C-arom), 150.63 (C-arom), 147.16 (C-arom), 140.10(C-arom), 127.38 (C-arom), 124.01(2 x C-arom), 116.39 (Carom), $115.36(2 \times$ C-arom $), 114.77(2 \times \mathrm{C}$-arom $), 55.60\left(\mathrm{O}-\mathrm{CH}_{3}\right), 54.63(\mathrm{~N}-\mathrm{CH}), 50.65(\mathrm{CO}-$ $\left.\mathrm{CH}_{2}\right), 30.66\left(\mathrm{CO}-\mathrm{CH}_{3}\right)$. 


\section{Knoevenagel Reaction}

Dimethyl 2-(3-methylbutylidene)malonate (17). $\quad 172 \mu \mathrm{L} \quad(1.55 \quad \mathrm{mmol})$ of 3 methylbutyraldehyde (16) was dissolved in $10 \mathrm{~mL}$ DMSO. The addition of $23 \mathrm{mg}(0.2 \mathrm{mmol}) \mathbf{1}$ was followed. After $5 \mathrm{~min} ., 459 \mu \mathrm{L}(4.00 \mathrm{mmol})$ dimethyl malonate (15) was added. The mixture was stirred overnight at rt. The reaction mixture was diluted with ethyl acetate and washed twice with water. The organic layer was dried over anhydrous $\mathrm{Na}_{2} \mathrm{SO}_{4}$. No further purification was needed. 270mg (1.35 mmol, 87\%) of product dimethyl 2-(3-methylbutylidene)malonate (17) was isolated. The reaction was carried out with cat. 2-6 in the same molar ratio. A yield of $85-90 \%$ was obtained. ${ }^{1} \mathrm{H}$ NMR $\left(400 \mathrm{MHz}, 298 \mathrm{~K}\right.$, ppm, in $\left.\mathrm{CDCl}_{3}\right): \delta=7.07(\mathrm{t}, J=7.9 \mathrm{~Hz}, 1 \mathrm{H},=\mathrm{CH})$, $3.84\left(\mathrm{~s}, 3 \mathrm{H}, \mathrm{OCH}_{3}\right), 3.80\left(\mathrm{~s}, 3 \mathrm{H}, \mathrm{OCH}_{3}\right), 2.21\left(\mathrm{dd}, J=6.9 \mathrm{~Hz}, J=7.8 \mathrm{~Hz}, 2 \mathrm{H}, \mathrm{CH}_{2}\right), 1.83(\mathrm{~m}, 1 \mathrm{H}$, $\left.\mathrm{CH}\left(\mathrm{CH}_{3}\right)_{2}\right), 0.96$ (s, 3H, $\left.\mathrm{CH}_{3}\right), 0.95\left(\mathrm{~s}, 3 \mathrm{H}, \mathrm{CH}_{3}\right)$.

\section{Acknowledgements}

The author would like to thank the Institute of Pharmaceutical Sciences, especially Prof. Michael Müller, Dr. Wolfgang Hüttel and Christian Klein. This research work was carried out in the laboratories of Prof. Müller. Hydroxyprolines $\mathbf{2}$ and $\mathbf{4}$ were supplied by Hüttel and Klein. the author also thanks DFG and DAAD for the financial support of his residency in Germany and Tafila Technical University (TTU) for the travel grant.

\section{References}

1. Berkessel, A.; Gröger, H. Asymmetric organocatalysis: from biomimetic concepts to applications in asymmetric synthesis. Wiley-VCH: Weinheim, 2005; pp 45-165.

2. $\quad$ Eder, U.; Sauer, G.; Wiechert, R. Angew. Chem. Int. Ed. 1971, 10, 496.

3. Hajos, Z. G.; Parrish, D. R. J. Org. Chem. 1974, 39, 1615.

4. Jarvo, E. R.; Miller, S. T. Tetrahedron 2002, 58, 2481.

5. Ahrendt, K. A.; Borths, C. J.; MacMillan, W. C. J. Am. Chem. Soc. 2000, 122, 4243.

6. List, B. Tetrahedron 2002, 58, 5573.

7. List, B.; Pojarliev, P.; Castello, C. Org. Lett. 2001, 3, 573.

8. Notz, W.; List, B. J. Am. Chem. Soc. 2000, 122, 7386.

9. $\quad$ Sakthivel, K.; Notz, W.; Bui, T.; Barbas III, C. F. J. Am. Chem. Soc. 2001, 123, 5260.

10. Trost, B. M.; Brindle, C. S. Chem. Soc. Rev. 2010, 39, 1600.

11. Zlotin, S. G.; Kucherenko, A. S.; Beletskaya, I. P. Russ. Chem. Rev. 2009, 78, 737.

12. List, B.; Pojarliev, P.; Martin, H. J. Org. Lett. 2001, 3, 2423.

13. Wang, Q.-W.; Peng, L.; Fu, J.-Y.; Huang, Q.-C.; Wang, L.-X.; Xu, X.-Y. Arkivoc 2010, $i i, 340$.

14. Kotrusz, P.; Toma, Š. Arkivoc 2006, $v, 100$. 
15. Rasalkara, M. S.; Potdara, M. K.; Mohilea, S. S.; Salunkhe, M. M. J. Mol. Catal. A: Chem. 2005, 235, 267.

16. Cordova, A.; Notz, W.; Zhong, G.; Betancort, J. M.; Barbas III, C. F. J. Am. Chem. Soc. 2002, 124, 1842.

17. Notz, W.; Tanaka, F.; Barbas III, C. F. Acc. Chem. Res. 2004, 37, 580.

18. Hoang, L.; Bahmanyar, S.; Houk, K. N.; List, B. J. Am. Chem. Soc. 2003, 125, 16.

19. List, B.; Lerner, R. A.; Barbas III, C. F. J. Am. Chem. Soc. 2000, 122, 2395.

20. Schmid, M. B.; Zeitler, K.; Gschwind, R. M., Angew. Chem. Int. Ed. 2010, 49, 4997.

21. Hartikka, A.; Arvidsson, P. I. Tetrahedron: Asymmetry 2004, 15, 1831.

22. Hartikka, A.; Arvidsson, P. I. Eur. J. Org. Chem. 2005, 4287.

23. Raj, M.; Vishnumaya, S. K. G.; Singh, V. K. Org. Lett. 2006, 8, 4097.

24. Hayashi, Y.; Sumiya, T.; Takahashi, J.; Gotoh, H.; Urushima, T.; Shoji, M. Angew. Chem. Int. Ed. 2006, 45, 958.

25. Zhang, S.-P.; Fu, X.-K.; Fu, S.-D. Tetrahedron Lett. 2009, 50, 1173.

26. Chimni, S. S.; Mahajan, D. Tetrahedron Lett. 2005, 46, 5617.

27. Chimni, S. S.; Mahajan, D. Tetrahedron: Asymmetry 2006, 17, 2108.

28. Gryko, D.; Lipinski, R. Adv. Synth. Catal. 2005, 347, 1948.

29. Gryko, D.; Lipinski, R. Eur. J. Org. Chem. 2006, 3864.

30. Tang, Z.; Jiang, F.; Yu, L. T.; Cui, X.; Gong, L. Z.; Mi, A. Q.; Jiang, Y. Z.; Wu, Y. D. J. Am. Chem. Soc. 2003, 125, 5262.

31. Berkessel, A.; Koch, A.; Lex, J. Adv. Synth. Catal. 2004, 346, 1141.

32. Tang, Z.; Yang, Z. H.; Chen, X. H.; Cun, L. F.; Mi, A. Q.; Jiang, Y. Z.; Gong, L. Z. J. Am. Chem. Soc. 2005, 127, 9285.

33. Samanta, S.; Liu, J. Y.; Dodda, R.; Zhao, C. G. Org. Lett. 2005, 7, 5321.

34. Cheng, C. L.; Sun, J.; Wang, C.; Zhang, Y.; Wei, S. Y.; Jiang, F.; Wu, Y. D. Chem. Commun. 2006, 215.

35. Chen, R. J.; Li, X. Y.; Xing, X. N.; Xiao, W. J. J. Org. Chem. 2006, 71, 8198.

36. Jiang, M.; F., Z. S.-.; Yang, Y.; Gong, L. Z.; Zhou, X. G.; Zhou, Q.-L. Tetrahedron: Asymmetry 2006, 17, 384.

37. Nakadai, M.; Saito, S.; Yamamoto, H. Tetrahedron 2002, 58, 8167.

38. Saito, S.; Nakadai, M.; Yamamoto, H. Synlett 2001, 1245.

39. Rulli, G.; Duangdee, N.; Baer, K.; Hummel, W.; Berkessel, A.; Gröger, H. Angew. Chem. 2011, 123, 8092.

40. Chandler, C. L.; List, B. J. Am. Chem. Soc. 2008, 130, 6737.

41. Yoshitomi, Y.; Makino, K.; Hamada, Y. Org. Lett. 2007, 9, 2457.

42. Gu, Q.; Wang, X. F.; Wang, L.; Wu, X. Y.; Zhou, Q. L. Tetrahedron: Asymmetry 2006, $17,1537$.

43. Klein, C.; Hüttel, W. Adv. Synth. Catal. 2011, 353, 1375.

44. Huang, P.-Q.; Huang, H.-Y. Synth. Commun. 2004, 34, 1377. 
45. Ait-Youcef, R.; Kalch, D.; Moreau, X.; Thomassigny, C.; Greck, C. Lett. Org. Chem. 2009, 6, 377.

46. Kofoed, J.; Darbre, T.; Reymond, J.-L. Chem. Commun. 2006, 1482.

47. Paradowska, J.; Stodulski, M.; Mlynarski, J. Angew. Chem. Int. Ed. 2009, 48, 4288.

48. Itoh, S.; Kitamura, M.; Yasuyuki, Y.; Aoki, S. Chem. Eur. J. 2009, 15, 10570.

49. Hara, R.; Kino, K. Biochem. Biophys. Res. Commun. 2009, 379, 882.

50. Mori, H.; Shibasaki, T.; Yano, K.; Ozaki, A. J. Bacteriol. 1997, 179, 5677.

51. Petersen, L.; Olewinski, R.; Salmon, P.; Connors, N. Appl. Microbiol. Biotechnol. 2003, 62, 263.

52. Bongaerts, J.; Esser, S.; Lorbach, V.; Al-Momani, L.; Müller, M. A.; Franke, D.; Grondal, C.; Kurutsch, A.; Bujnicki, R.; Takors, R.; Raeven, L.; Wubbolts, M.; Bovenberg, R.; Nieger, M.; Schürmann, M.; Trachtmann, N.; Kozak, S.; Sprenger, G. A.; Müller, M., Angw. Chem. Int. Ed. 2011, 50, 7781.

53. Al-Momani, L.; Lorbach, V.; Detry, J.; Geilenkirchen, P.; Müller, M., Manuscript is submitted. 